\title{
The Professional Practice Content Innovation of the Training Mode of Information Innovative Talents
}

\author{
Henghua Shi ${ }^{1, a}$, Xin $\mathrm{Xu}^{2, b,{ }^{*}}$, Xiaoshun $\mathrm{Li}^{1, \mathrm{c}}$ and Xiaotong Liang ${ }^{1, \mathrm{~d}}$ \\ ${ }^{1}$ School of Computer and Information Engineering, Beijing University of Agriculture, China \\ ${ }^{2}$ Communication Technology Bureau, Xinhua News Agency, China \\ ahenghuashi@163.com, byouges@163.com, '9xs@bua.com, dxt@bua.com \\ ${ }^{*}$ Corresponding author
}

Keywords: Innovation; Training Mode; Innovative Talents; Further Education; Entrepreneurship

\begin{abstract}
With the training direction of information talents and the characteristics of information technology development, the training mode of information innovative talents needs continuous exploration. In this paper, we combine the training mode of " $3+1 "$ talents with that of information innovative talents. Then, we innovatively propose the professional practice content of the training mode of " $3+1$ " information innovative talents.
\end{abstract}

\section{Introduction}

With the constant change of society's demand for information talents, new demands have been proposed for the types of information talents. That is the information innovative talents. The so-called "innovative talents" is full of originality, creativity, to propose and solve problems, create a new situation, make a creative contribution to the social material and spiritual civilization of human [1]. The proposed kind of information innovative talents can promote the promotion of training and employment, but the professional practice content of the current training of information innovative talent is carried out with the original general training mode of information talents [2-5]. This is the lack of innovation, and cannot adapt to the needs of employment, entrepreneurship, further education.

In this paper, we combine the training mode of " $3+1 "$ talents and that of information innovative talents, and innovatively propose the professional practice content of the training mode of " $3+1$ " information innovative talents.

\section{The Different Directions of the Training Mode}

With the implementation of the national "widespread entrepreneurship and innovation " policy, the new directions is proposed as entrepreneurship with the original employment and further education directions. Then, the current information talents training direction can be divided into three directions such as employment, entrepreneurship and further education.

For the employment direction of information talents, the domestic universities have changed the training mode from "3.5+0.5" into "3+1"[6]. This can effectively use the resources of schools and enterprises, and make up their respective shortcomings. The so-called " $3.5+0.5$ " model, is the first undergraduate students three and a half years in school, mainly to complete the basic knowledge and theory of learning into practice to do the preparatory stage and the accumulation of knowledge; then use the last half year in the enterprise practice and practice, the enterprise provides students with a real occupation environment. This model can improve students' practical ability [1]. The so-called " $3+1$ " model, is based on the original " $3.5+0.5$ " model, further compression of the learning cycle in the school, thus extending the practice in the enterprise. This model made information talents employment better, and is effective in the training of " $3+1$ " information talents in solving the employment problem. However, there are no effective methods for entrepreneurship 
and further education, and lack the professional practice content of the training mode of the innovation talents[7-10].

For the consistency of the training time of information talents, the training mode of " $3+1$ " talents adopted in the employment direction will be applied to the other two direction. Therefore, the entrepreneurship and further education directions will be taken the training mode of " $3+1$ " talents. It means the students learn at school with the undergraduate three years time. Different with the employment direction, the other two directions are not to the enterprise practice, practice. For the entrepreneurship direction, we should provide targeted business knowledge training and enterprise registration guidance. For the further education, we should provide review sites and the entrance examination information consulting personnel.

\section{The Professional Practice Content of the Training Mode}

Combined with the existing training mode of " $3+1 "$ talents, and according to the special requirement of innovative talents training. We make adjustment and riching the professional practice content of the training mode of the employment direction based on the training mode of the original information talents. At the same time, we should innovate the professional practice content of the training mode of the entrepreneurship and further education direction. Then, we get the preliminary form of the professional practice content of the training mode of " $3+1$ " information innovative talents as the following:

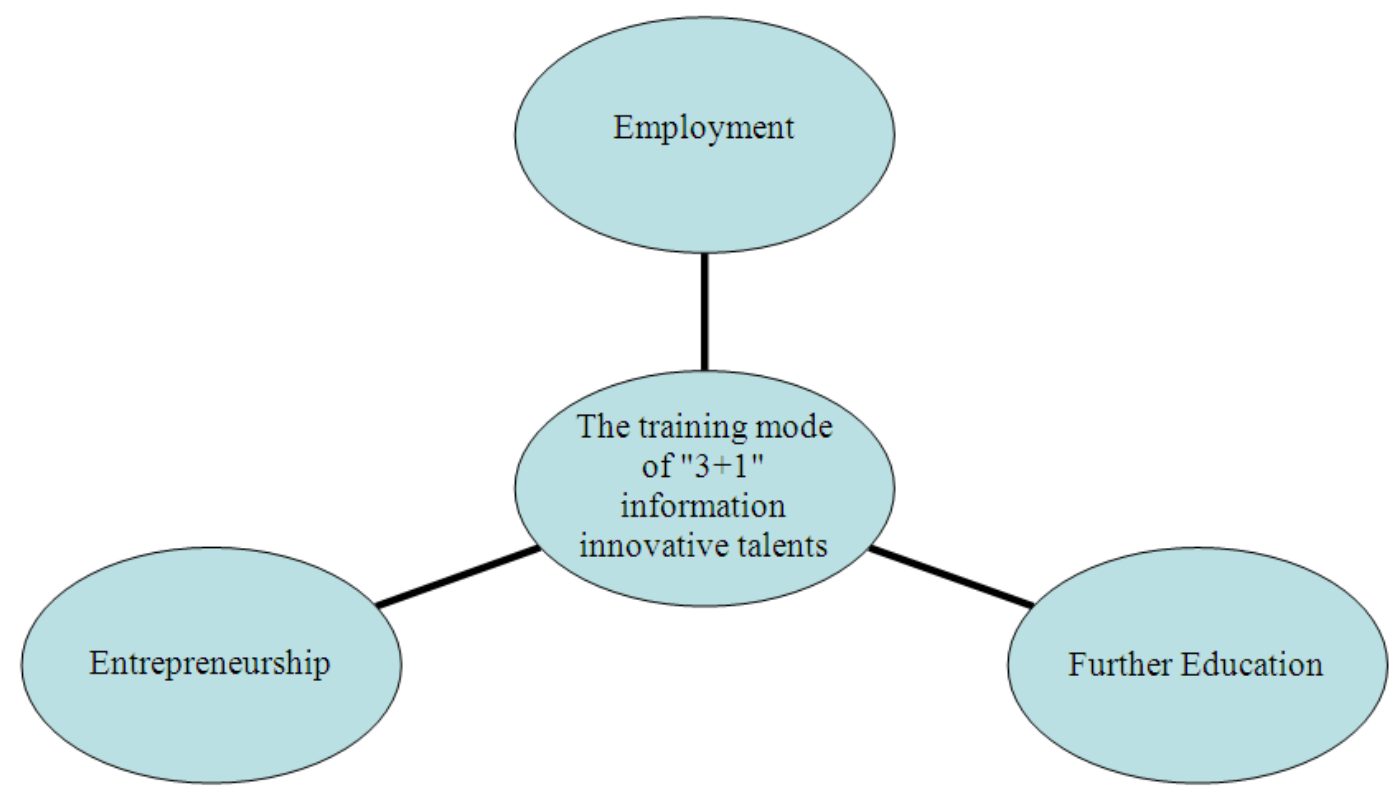

Fig. 1 The professional practice content of the training mode of " $3+1$ " information innovative talents

\section{The Training Mode Content of the Different Directions}

The three different directions such as employment, entrepreneurship, further education decided that the training mode content of " $3+1$ " information innovative talents is different. We should draw up the specific personnel training mode according to the specific direction and demand.

The Employment Direction. The employment direction is the main direction of talent training, and most undergraduates choose this direction to carry out internship, training and job placement as the last year of " $3+1$ ". In recent years, domestic universities in the employment direction of accumulated rich enterprise practice information, personnel training, and establish the related enterprises good complementary way, also achieved good effect of employment information talents. However, there are still some problems, among them, the technical requirements of enterprise posts 
are inconsistent with the content of personnel training in Colleges and universities, and the problems are more prominent. The main reason for this problem is the development characteristics of information technology itself. The main features of the development of information technology is a technology update speed, new technology and domestic university information emerge in an endless stream, talent cultivation due to the provisions of the national education policy limit is difficult to get along with the development of new technologies and corresponding changes, which led to the domestic information talents training in University does not adapt to the development of new technology, knowledge required the content behind the enterprise post technical requirements.

To solve this problem, it is necessary for domestic universities to meet the requirements of innovative talents and formulate and adjust the professional practice content of the training mode of information talents in light of the trend of information technology development. At the same time, we should combine with " $3+1$ " in the last year of enterprise internship training, enterprises and social needs of new technologies introduced into the training of talent. The technical requirements of the post as the formulation and adjustment of training mode of talents on the basis of information content, the content of curriculum theory and practice to develop the experimental content, and gradually form a interactive knowledge system and enterprise post technical requirements and docking of personnel training in Colleges and universities.

The Entrepreneurship Direction. The entrepreneurship direction is a new direction of talent training for the implementation policy of "widespread entrepreneurship and innovation". It is also a useful supplement to the talent training model in employment direction. At present, domestic universities in the entrepreneurial orientation has not developed specific the professional practice content of training content, there is no basis for reference, so the need for training mode of entrepreneurial direction " $3+1$ " information of innovative talents for the exploration and innovation. According to the relevant regulations of the state on University Students' entrepreneurship, two aspects of entrepreneurship training and enterprise registration guidance should be carried out in accordance with the spirit of training and guiding entrepreneurship. Entrepreneurship knowledge training, including the provision of entrepreneurship related provisions, training, entrepreneurship examples of interpretation, inviting individuals to face the face of entrepreneurship, entrepreneurship and other content. Enterprise registration guidance is convenient, including enterprise management training, enterprise registration, content explanation and so on.

The Further Education Direction. With the continuous supply of talents in the society, the degree of education has become an important standard for enterprises to measure talents. More and more undergraduates choose to enter the higher school to improve their knowledge and ability and lay the foundation for better jobs in the future. Domestic colleges and universities for further undergraduate students without special treatment, and the direction of employment need for internship training, post, to a certain extent affected the students review PubMed, while the corresponding internship training, post has not achieved good results. In recent years, in order to meet the demand of domestic university entrance direction of personnel training, put forward the training mode of centralized and personal review combined to review the main personal talents, and strengthen the relevant information and consulting services, to determine a good education effect.

\section{Summary}

With the characteristics of technology update speed, new technology development emerge in an endless stream of information technology, and information professionals and employment, entrepreneurship, further education and other directions, so the information innovative talents requires continuous exploration and innovation in the training mode. According to the new demand information innovative talents, we combine the training mode of " $3+1 "$ talents with that of information innovative talent. Then, we innovatively propose the three directions of the professional practice content of the training mode of " $3+1$ " information innovative talents such as employment, entrepreneurship, further education. 
A multi-dimension, multi-level and multi stage collaboration of the training mode of " $3+1$ " information innovative talents is the future of a period of information talents cultivation direction.

\section{Acknowledgement}

Corresponding author is $\mathrm{Xu} \mathrm{Xin}$. The authors would like to acknowledge the supports provided by 2017 Education and Teaching Reform Program of Beijing University of Agriculture "The Exploration and Practice of the Training Mode of ' $3+1$ ' Information Innovative Talents"

\section{Reference}

[1] Xu Songpu, et al. Exploration and Practice of Personnel Training Mode of Information Talents “3.5+0.5” . China Education Innovation Herald. 2008 (35) 15.

[2] Zhao Huajun, et al. Exploration and Practice of Applied Talents Training Mode of Electronic Information Science and Technology. Chongqing Higher Education Research, 2007, 26 (1): 73-75

[3] Liu Wangjun, et al. Study and Practice of the Talents Cultivation Mode Major for the Electric Information Engineering. Journal of Hunan Institute of Engineering (Socoal Seience Educiton), 2006, 16 (1): 80-81

[4] Wang Jinting, et al. Training of Innovative Talents of Electronic Information in Application-oriented Universities. Journal of Hubei University of Economics (Humanities and Social Sciences), 2013 (7): 186-187

[5] Ye Mingfeng, et al. Research and Practice of Personnel Training Mode for Information and Computing Professionals in the New Century. China market, 2008, 21 (2): 3-6

[6] Song Zuozhong, et al. Research on Personnel Training Mode of "3+1" in School Enterprise Cooperation. Heilongjiang Higher Education Research, 2013, 31 (5): 154-157

[7] An, Jiang Ying, et al. Exploration and Practice of Innovative Talents Training Mode in Chinese Universities. China Electric Power Education, 2006 (1): 29-32

[8] Guo Xingqi, et al. Comparison of Training Mode of Innovative Talents Among College Students at Home and Abroad. Higher Agricultural Education, 2009 (2): 89-91

[9] Li Bing, et al. Study on Training Mode of Entrepreneurial Talents. Chinese Collective Economy, 2014 (5): 88-90

[10] Guo Juan, et al. College Student's Innovative Entrepreneurial Talents Training Mode Study. Science and Technology Information, 2011 (31): 186-187 